\title{
Symbolic meaning and use of broad beans in traditional foods of the Mediterranean Basin and the Middle East
}

\author{
Antonella Pasqualone ${ }^{1 *}$ (D) Ali Abdallah ${ }^{2}$ (D) and Carmine Summo ${ }^{1}$ (B)
}

\begin{abstract}
Broad beans (Vicia faba L.) are rarely consumed in Northern Europe and in the USA, whereas they are constantly present in the culinary habits of the Mediterranean and Middle Eastern countries. This grain legume is characterized by interesting nutritional properties because of high levels of complex carbohydrates, proteins, and dietary fiber, coupled with a low content of saturated lipids and the presence of several bioactive compounds. However, broad beans are much more than a cheap source of nutrients. Among the oldest domesticated legumes, they have also a cultural value linked to an ancient symbolic meaning. Generally associated with funerary rituals, broad beans have also a positive significance being "dead" seeds with a regenerative capacity. This review focuses on the social symbolism of broad bean consumption and its associated rituals. Furthermore, the culinary habits related to this legume are analyzed along different Mediterranean and Middle Eastern countries, from Egypt to Iran. Soups, thick gruels, and purees were found to be by far the most common culinary preparations. Using the Egyptian ful medames as a model, the study highlights a link between broad bean-based dishes in different countries, which arises from similar environmental conditions and from cultural interactions along trade routes. Enhancing the knowledge of these ethnic legume-based foods could improve the diet of Western countries by increasing the consumption of legumes.
\end{abstract}

Keywords: Vicia faba L., faba bean, Nutritional composition, Anthocyanins, Bioactive compounds, Ful medames, Puré di fave e cicorie, Food of the dead, Symbolic food, Ethnic food, Food culture

\section{Introduction}

Vicia faba L. (family Fabaceae) is one of the oldest domesticated pulses. The earliest evidence of its farming dates back to 10,200 years ago in the Southern Levant [1]. As other edible plant species, pulses were first collected by hunter-gatherers. Then, together with cereals, pulses became part of the "agricultural revolution," spreading in post-glacial Europe [2]. V. faba has

\footnotetext{
* Correspondence: antonella.pasqualone@uniba.it

Dedicated to the memory of Dr. Suha Ashtar, General Commission for Scientific Agricultural Research (GCSAR), Plant Biotechnology Lab., Aleppo Center, Aleppo, Syria.

'Department of Soil, Plant and Food Science (DISSPA), Food Science and Technology Unit, University of Bari 'Aldo Moro', Via Amendola, 165/a, I-70126 Bari, Italy

Full list of author information is available at the end of the article
}

an efficient atmospheric nitrogen-fixing ability and well adapts to climate change, hence could feed future generations $[3,4]$.

Based on seed size, three botanical $V$. faba varieties are distinguishable, although the classification is not always effective due to environmental influence on this character. Vicia faba major, or broad bean (named "fava bean" in the USA, from the Italian word fava which means "broad bean") [5], has seeds having thousand seed weight higher than $1000 \mathrm{~g}$. Vicia faba var. equina, or horse bean, has seeds of intermediate size (thousand seed weight from 700 to $1000 \mathrm{~g}$ ) whereas Vicia faba minor, or faba bean, also named field bean, has smaller seeds (thousand seed weight from 500 to $700 \mathrm{~g}$ ) [6]. Broad bean is cultivated for edible use, whereas horse

(c) The Author(s). 2020 Open Access This article is licensed under a Creative Commons Attribution 4.0 International License, which permits use, sharing, adaptation, distribution and reproduction in any medium or format, as long as you give appropriate credit to the original author(s) and the source, provide a link to the Creative Commons licence, and indicate if changes were made. The images or other third party material in this article are included in the article's Creative Commons licence, unless indicated otherwise in a credit line to the material. If material is not included in the article's Creative Commons licence and your intended use is not permitted by statutory regulation or exceeds the permitted use, you will need to obtain permission directly from the copyright holder. To view a copy of this licence, visit http://creativecommons.org/licenses/by/4.0/. 
bean is mostly used as animal feed, and faba bean for crop rotation and livestock nutrition. The amount of beans used for animal feed is greater than for human consumption [7]. Besides seed size, also seed color can vary considerably among varieties (Fig. 1), from greenish-beige to brown and violet [8].

The greatest global producer of $V$. faba (considering broad beans and horse beans together) is China (Fig. 1), with 1,806,000 tons in 2018, followed by Ethiopia (988, 000 tons), the UK (402,000 tons), Australia (388,000 tons), Germany, Morocco, France, and Egypt (around 150,000 tons each), Italy and Sudan (around 100,000 tons each) (Food and Agriculture Organization, 2019). Although with lower production, $V$. faba is the most cultivated legume in Algeria and Tunisia [9].

This review analyzes the nutritional quality of $V \cdot f a b a$ and the culinary habits related to broad beans in the area of greatest consumption, i.e., along the Mediterranean Basin and the Middle Eastern countries, from Egypt to Iran. Furthermore, this review focuses on the social symbolism of broad bean consumption and associated rituals in the same geographic area.

\section{Vicia faba L. nutritional quality}

$V$. faba has a very low content of saturated fatty acids and is an excellent source of proteins, complex carbohydrates and dietary fiber $[8,10]$. Lysine is present at high concentrations, whereas the content of methyonine and cysteine is low [8], making the combination with cereals able to meet dietetic requirements.

The composition of seeds, however, varies according to the variety. The $V$. faba samples shown in Fig. 1, which were characterized by different phenotype and geographical origin, had a total fiber content ranging from 13.6 to $24.3 \mathrm{~g} / 100 \mathrm{~g}$ on dry matter (d.m.) (Fig. $2)$. Minor variations affected the content of carboydrates $(52.7 \pm 3.5 \mathrm{~g} / 100 \mathrm{~g}$ d.m.), proteins $(25.2 \pm 1.1 \mathrm{~g} /$ $100 \mathrm{~g}$ d.m.), lipids (1.5 $\pm 0.3 \mathrm{~g} / 100 \mathrm{~g}$ d.m.), and ashes $(3.4 \pm 0.3 \mathrm{~g} / 100 \mathrm{~g}$ d.m.). The level of saturated fatty acids (mean value $19.5 \mathrm{~g} / 100 \mathrm{~g}$ d.m.) was much lower than polyunsaturated fatty acids (mean $57.9 \mathrm{~g} / 100 \mathrm{~g}$ d.m.) confirming the data available in literature [11]. Polyunsaturated fatty acids have been detected also in green pods [12].

Faba beans contain also secondary metabolites, such as phenolic compounds [13-15]. These antioxidant minor constituents are though to play a role in disease prevention. Among them, anthocyanins are present only in violet seeds, where are responsible for pigmentation [16]. Other compounds, however, are antinutritional factors, such as tannins, phytates, stachyose, saponins, and lectins $[8,17,18]$. Tannins (proanthocyanidins) are related to seed coat color: lighter seeds have lower tannin content [8], and tannin-free $V$. faba varieties have almost white seeds [19]. As for phytates, the breeders made available varieties having low phytates and high phytase activity [20].

Regarding the $V$. faba samples shown in Fig. 1, total anthocyanins varied considerably: from 2.7 to $108.3 \mathrm{mg}$ cyanidin 3-O-glucoside/kg d.m. in the greenish-beige (coded 112082 ) and in the violet variety (coded 106560), respectively (Fig. 2). The total carotenoids varied from 8.9 to 16.8 mg $\beta$-carotene $/ \mathrm{kg}$ d.m., while minor variations were observed for phenolic compounds and phytates.

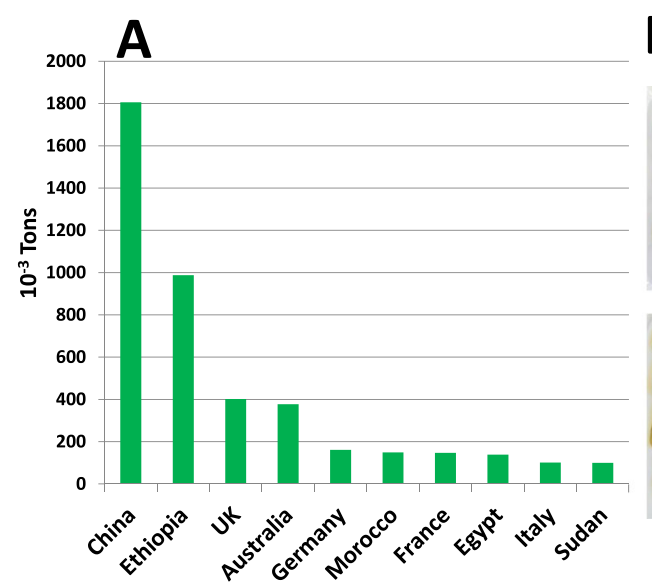

B
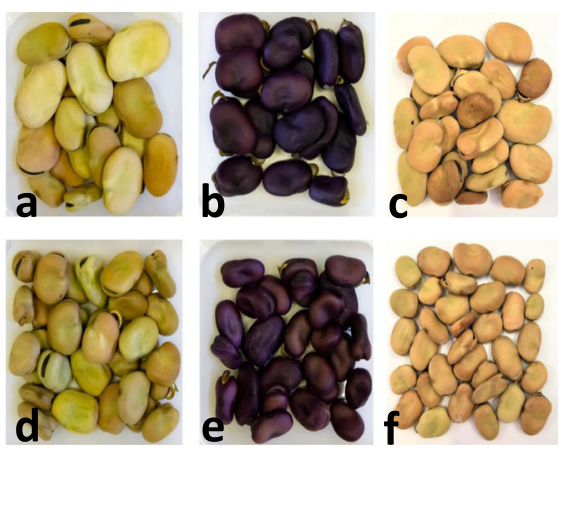

Fig. 1 World production and phenotypic biodiversity of $V$. faba. a First 10 producers of broad and horse beans in 2018 (tons). The greatest world producer is China, followed by Ethiopia. (Own elaboration from FAO data available in: http://www.fao.org/faostat/en/\#data/QC). b Dry seeds of $V$. faba having different size (from small to large) and coat color (greenish-beige, violet and light brown), as an example of phenotipic biodiversity within the species. Their unambiguous identification number and geographic origin are: $a=112082$ (Morocco); b = 106560 (Sicily, Italy); c = 110195 (Apulia, Italy); $d=108425$ (Egypt); $e=110184$ (Apulia, Italy); $f=111894$ (Lybia). The samples are from the Institute of Biosciences and Bioresources of the National Research Council of Italy (IBBR-CNR). More information about them and the collecting site are available in the Mediterranean Germplasm Database, available in: http://ibbr.cnr.it/mgd/?action=search\&p=spp 

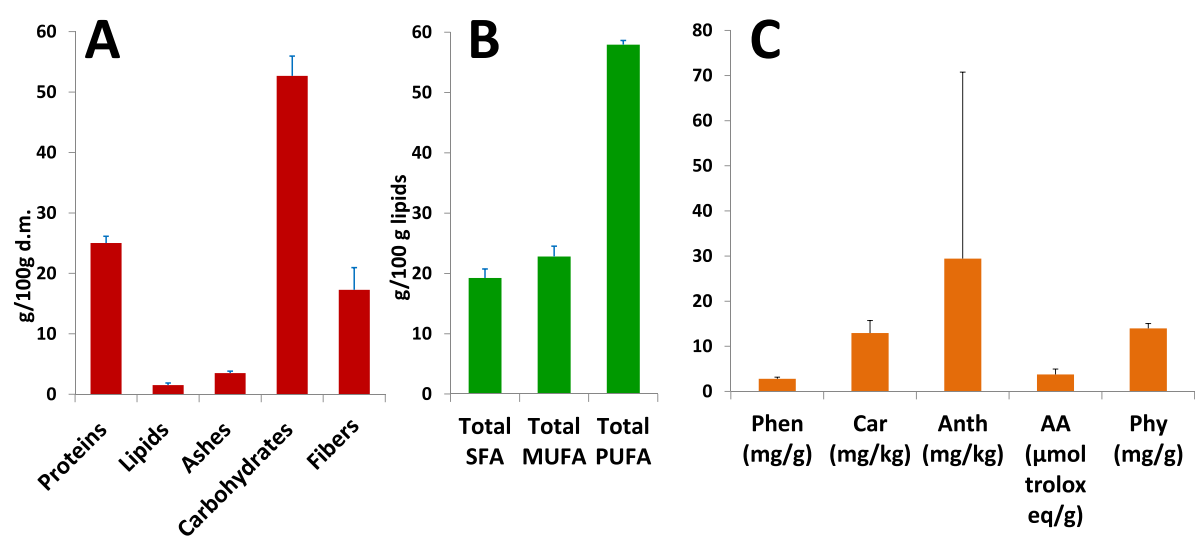

Fig. 2 Nutritional composition, fatty acid profile and bioactive compounds of the $V$. faba samples shown in Fig 1 (mean \pm standard deviation). a The nutritional composition of $V$. faba is characterized by a very low content of lipids and is a good source of complex carbohydrates, proteins, dietary fiber and mineral salts. The composition varies according to the variety, with larger variations for the total fiber content. $\mathbf{b}$ The fatty acid profile of $V$. faba is very healthy because is characterized by a very low content of saturated fatty acids and a high content of polyunsaturated fatty acids. (SFA = saturated fatty acids; MUFA = monounsaturated fatty acids; PUFA = polyunsaturated fatty acids). $\mathbf{c}$ Among the bioactive compounds, anthocyanins show the largest variations, being more concentrated in the violet varieties of $V$. faba. The other compounds, namely phenolics, carotenoids and phytates, as well as the antioxidant activity, show limited variations. (Phen = total phenolics; Car = total carotenoids; Anth = total anthocyanins; $\mathrm{AA}=$ antioxidant activity; Phy = total phytates)

The content of antinutrients is generally reduced by peeling (dehulling), sprouting, soaking, boiling [17, 18], and extrusion cooking [21]. Significant leaches in the soaking medium have been reported also for phenolic compounds [22]. The phenolic content and antioxidant activity of faba beans are affected by cooking [13, 14, 21].

$V$. faba seeds contain also specific glycosides, namely vicine and convicine [8], which are implicated in favism, a hemolytic anemia occurring in people carrying a genetic deficiency of glucose-6-phosphate dehydrogenase (G6PD) [23]. These glycosides can be greatly reduced by soaking the seeds [24] and by thermal processing, such as boiling, roasting, microwaving, and frying $[25,26]$, as well as by fermentation [27].

Compounds of interest are choline [28] and levodihydroxy-phenylalanine (L-DOPA) [29]. The first is essential for the synthesis of phospholipids of cell membranes and for cholinergic neurotransmission in humans [30], whereas L-DOPA, found in seedlings, green pods, and seeds of $V$. $f a b a$, is the precursor of the neurotransmitter dopamine [29].

\section{Symbolic meaning of broad beans}

All the seeds, such as grains and legumes, are "dead" but have a positive significance because of their regenerative capacity. In ancient times the seeds, and in particular broad beans, were associated with death and the deceased [31, 32]. The ancient Romans believed that the plant of faba bean was directly linked with the underworld due to its long roots and stem with little ramifications (Fig. 3) [31, 33], therefore this plant was considered able to bring the dead back to the world of the living. Moreover, broad beans were said to house the souls of the dead [31]. The black spots on the flowers (Fig. 3) were associated with mourning. At Roman funerals, broad beans were spread over the tombs to give peace to the deceased [31], whereas toasted broad beans were distributed, together with bread, during the dies parentales (literally, in Latin, "days for celebrating the memory of the family's dead") [34].

The celebration of All Souls' Day, instituted in the monastery of Cluny (France) in 998, was the Christianization of an old Celtic feast in honor of the dead [31]. On All Souls', the dead were supplied with grains and legumes through direct offerings, keeping an empty place at the table for the dead, or as alms for beggars and poor people in suffrage of the dead.

In Italy, broad beans were distributed to the poor during funerals [35], and also, in Malta, these beans were a typical "funeral food" [36]. On the other hand, food in a broad sense plays a central role also in the celebration of the Islamic funeral [37]. The funerary banquet, similar to the consolo (banquets made in Southern Italy for "consoling" the relatives of the deceased for the loss of the beloved), typifies the symbolic relations between the living and the dead [38]. A similar role is played by food offerings to the poor during the Islamic celebrations following the Ramadan: Eid al-Fitr ("Festival of breaking the fast") and Eid al-Adha ("Feast of the sacrifice") [37].

The ceremonial distribution of stewed legumes (most often broad beans) or cereals to singing beggars and children was traditional on All Souls' in Italy during the Middle Ages and up to the nineteenth century (Fig. 4), 

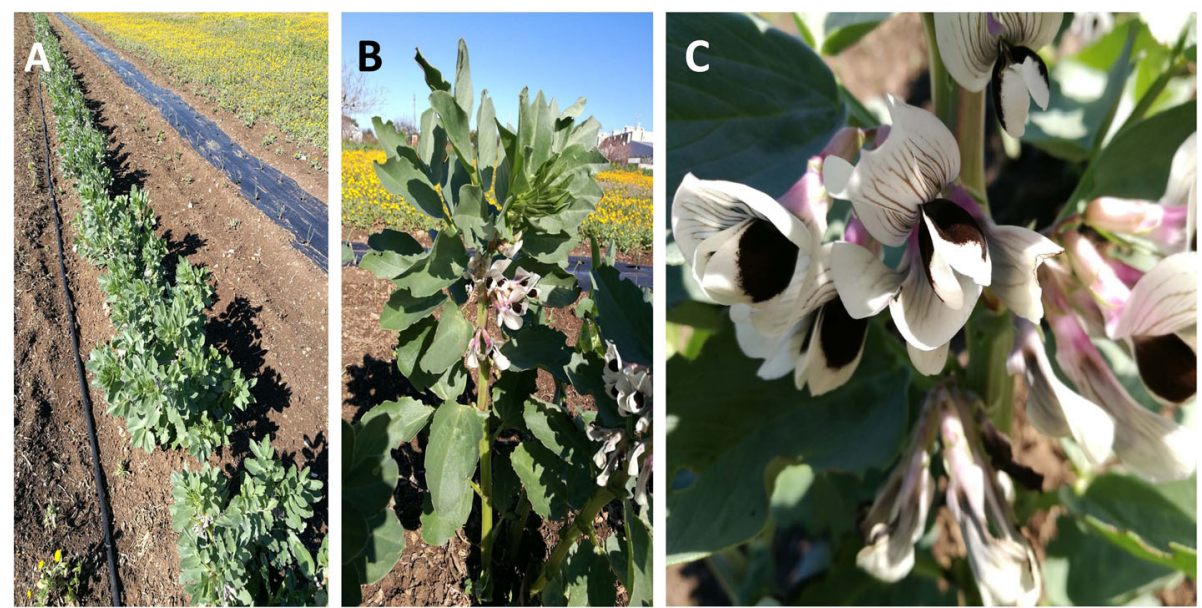

Fig. 3 V. faba plants and flowers. a A row of V. faba plants cultivated in a field located in Bari (Apulia, Southern Italy). Sown in November, flowering at the end of February, faba beans are usually harvested in April-May, when the seeds and the pods can be eaten fresh. After that period, they are marketed mostly as dry seeds. $\mathbf{b}$ A single $V$. faba plant, with the stem free of nodules and little ramifications. The ancient Romans believed that the plant of faba bean was directly linked with the underworld due to its long roots and slightly branched stem, therefore this plant was considered able to bring the deceased back to the world of the living. $\mathbf{c}$ Flowers of Vicia faba L. with the typical black spot in the center of the white petals. In ancient times, the bean flower was considered a sign of mourning because of the black spot

and people themselves consumed such food named cibo dei morti (in Italian "food of the dead") [31]. A similar custom was, in ancient times, quite common along the coasts of the Mediterranean Basin [39]. By eating seeds, human beings could perpetuate life, while the dead could be reborn to a new life [31].

According to an old popular belief, the dead visited their homes on the night before All Souls' Day bringing sweets to children of their family, such as small cookies shaped as broad beans, named fave dei morti (literally, in Italian, "broad beans from the dead") (Fig. 5), or cookies shaped as bone pieces, named ossa dei morti (meaning "bones of the dead") (Fig. 5) [31]. The main door of the house was left open and a plate with some food was kept at the table, for the soul of the deceased. The traditional custom of preparing fave dei morti and ossa dei morti for celebrating All Souls' still survives in several Italian regions [31, 40].

Broad beans and other legumes are most often sown in late autumn/mid-winter, a period that can be considered an agricultural new year because of the annual regeneration. In Southern Italy, the distribution to the poor of cooked grains and legumes took place in the past also on the day of Saint Lucy (December 13), near the mid-winter solstice, after which the daylight starts increasing again. Cereal grains or legumes were also ceremoniously consumed and distributed to the poor in other special days of the same period, such as for lentils on New Year's Eve (December 31), and broad beans on the day of Saint Anthony (January 17) [31].

Furthermore, since broad beans are very nutritious, they are eaten before sunrise during the Islamic
Ramadan, to help people fast more easily during the daytime. Similarly, during the Christian Lent, which involves refraining from eating meat, broad beans are eaten more frequently.

\section{Broad beans in the traditional gastronomy}

In recent years there has been an increase in the consumption of pulses in Western countries, where they are increasingly considered healthy foods, paralleling the growing number of vegetarian/vegan consumers. The United Nations encouraged this increase by declaring 2016 as "International Year of Pulses" (IYP) prompt by "the need to heighten public awareness of the nutritional benefits of pulses and to further sustainable agriculture" [41].

However, the consumption of broad beans is still seldom found in Northern Europe and the USA, except as roasted and salted seeds for a snack [42]. On the contrary, broad beans are a traditional staple food throughout the Mediterranean Basin and the Middle East, as well as in India, Pakistan, and China.

Broad beans are usually marketed dried and eventually peeled (split broad beans) (Fig. 6). Peeling, in fact, allows to shorten cooking times. When available, the fresh product is also consumed: seeds and pods are marketed fresh at the time of harvest, or frozen, to be used as vegetables (Fig. 6).

Broad beans can be cooked in several ways, including stewing, baking, and frying (Fig. 7). Fresh seeds can be eaten also raw. However, soups, thick gruels, and purees are by far the most common culinary preparations, 


\begin{tabular}{|c|c|}
\hline \multirow[t]{2}{*}{$\begin{array}{l}\text { CODICE DIPLOMATICO } \\
\text { DELLE RELAZIom } \\
\text { FRA LA LIGURIA } \\
\text { LA TOSCANA E LA LUNIGIANA } \\
\text { AI TEMPI DI DANTE } \\
\text { (I265 - I321) }\end{array}$} & 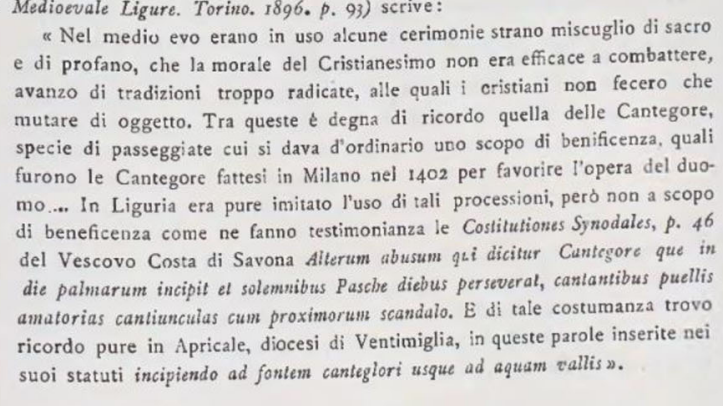 \\
\hline & $\begin{array}{l}\text { Le Cantegore si usano tuttavia nei paesi della riviera e delle valli piú vi- } \\
\text { cine a Genova per le questue, che dopo la stagione della vendemmia, per } \\
\text { turto ottobre, sino a S. Martino, a mezzo novembre, si vanno facendo a suf- } \\
\text { fragio dei defunti. }\end{array}$ \\
\hline
\end{tabular}

Fig. 4 Traditional customs on All Souls' Day in Italy. Title page of a book dating back 1901 by Arturo Ferretto, who collected all the documents from 1265 to 1321 constituting il codice diplomatico delle relazioni tra la Liguria, la Toscana e la Lunigiana ai tempi di Dante, i.e., "the diplomatic code of the relationships between some regions of Northern Italy (Liguria, Lunigiana, and Tuscany) at the times of Dante Alighieri." This book reports about the use of giving cantegore and explains that the cantegore were songs for the souls in purgatory that, during the Middle Ages, were traditionally sung by young people in the period from October to mid-November (and in particular on All Souls' Day), as they walked begging for various foods, including faba beans. This medieval tradition survives in a few places in Italy, but traditional seasonal sweets are given away instead of beans and grains. (The digital document is from Società Ligure di Storia Patria. Biblioteca digitale.

2011. https://www.storiapatriagenova.it/Docs/Biblioteca_Digitale/SB/619ed2f0c43179836ebfd1c242eb3493/767cae010882c8c7d724846b01a31392. pdf).

constantly present in the gastronomy of the Mediterranean and Middle Eastern countries.

\section{Egypt: Ful medames}

In Egypt, faba beans are largely consumed [5]. Egyptians eat faba beans in various ways, the most popular of which is a dish named ful medames (or ful/foul medam mes/mudammes/mudammas/midammis), or simply ful (pron. fül). Ful medames is a very simple dish composed of whole or mashed broad beans. Very cheap, sold by street vendors with their traditional carts (Fig. 8), or in restaurants, ful medames is so popular that it can be considered the Egyptian national dish [43]. Able to satiate for a whole day due to its high fiber content, ful

A

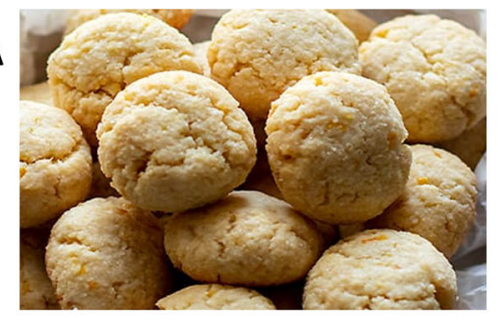

B
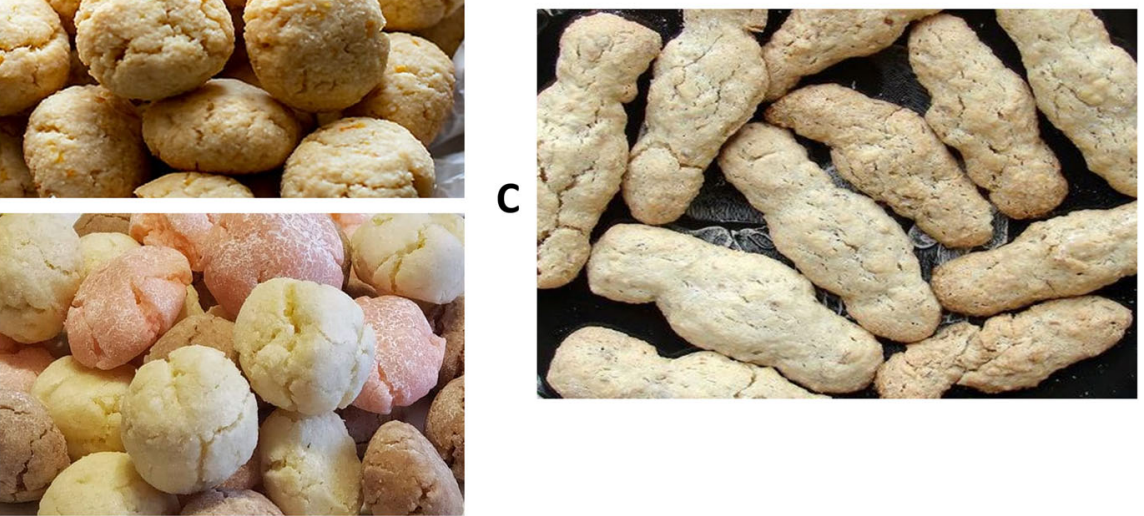

Fig. 5 Traditional sweets consumed on All Souls' Day in some regions of Italy. a Small cookies shaped as broad beans, named fave dei morti (literally, in Italian, "broad beans from the dead"). These cookies, basically made of almond flour and sugar, are usually prepared for celebrating All Souls' in several Italian regions, such as Liguria, Veneto, Emilia Romagna, Lazio, Lombardia, Marche, and Umbria. b A slightly colored version (pale yellow, pink and pale brown) of the broad bean shaped cookies fave dei morti. This version is typically consumed in Friuli Venezia Giulia and particularly in the area of Trieste, Italy. c Cookies shaped as bone pieces, named ossa dei morti (meaning "bones of the dead"). They are traditionally prepared for celebrating All Souls' in Sicily, but also in several regions of Northern Italy, such as Piemonte, Lombardia, Veneto, and Tuscany 
medames is usually consumed at breakfast. During Ramadan, this dish is eaten before sunrise, to help people fast more easily during the daylight hours.

Ful is the Egyptian Arabic word for "broad bean," whereas medames means "buried," referring to the original cooking method, which involved burying a pot, containing water and beans, under hot coals to cook overnight. Ful medames is typically prepared using dried broad beans, which have to be soaked in water to soften prior to cooking. Then, the beans are drained, added fresh water, and cooked slowly on the stove with a very faint flame, until tender (6 or $7 \mathrm{~h}$ ) [43]. A special pot, a ful-pot, narrow at the base, wide in the middle, and narrow again at the top, is traditionally used (Fig. 9). This special pot is named damasa (or dammasa), being this word the adjective of tadmiis, which means "stewing." Alternatively, the name of the pot is qidra el-ful, where quidra generically means "pot" in Arabic, but with the specification, el-ful becomes the pot used for preparing ful medames. The pots are made of copper (the oldest), aluminum, or stainless steel. Their size changes from small, only for domestic use, to large, such as those of the street vendors and restaurants (Fig. 9).

To meet the needs of modern consumers, cooking times can be shortened to $30-45 \mathrm{~min}$ by using a pressure cooker. Another strategy involves using smallsized beans. To skip totally home preparation, however, canned ful medames is largely marketed nowadays (Fig. 8).

Once cooked, the broad beans can be either kept whole or mashed, partly or completely, by a fork or a blender (Fig. 9). The skins are not removed; therefore, the characteristic color of ful medames is brown. Basic seasoning is composed of salt, oil, lemon juice, and cumin; then, other ingredients may be added to obtain different variants: tahini (sesame seed sauce), tomato sauce, or chili (Fig. 9) [43]. The dish can be garnished with lemon slices, finely diced tomatoes, onions, and cucumbers. A boiled egg can also be added and mashed into the beans, as well as cheese or cured beef (pastirma). Ful medames is served with the traditional flatbread [44], which can be used as a spoon to scoop up the ful.

Regarding oil, the most used in the preparation of ful medames are corn, sunflower, and linseed oil, the latter very spicy and therefore named zyit har, which means "spicy oil." Also, clarified butter (samna) can be used.

Ful medames usually goes together with another Egyptian popular dish made of broad beans named ta'meya (or ta'miyya), well known also abroad as falafel. It has to be noted that in Lebanon falafel is made of chickpeas, whereas in Egypt, only broad beans are used. In Egypt, the combination ful and falafel is as popular as "fish and chips" in the UK. Ta'meya or falafel are legume fritters
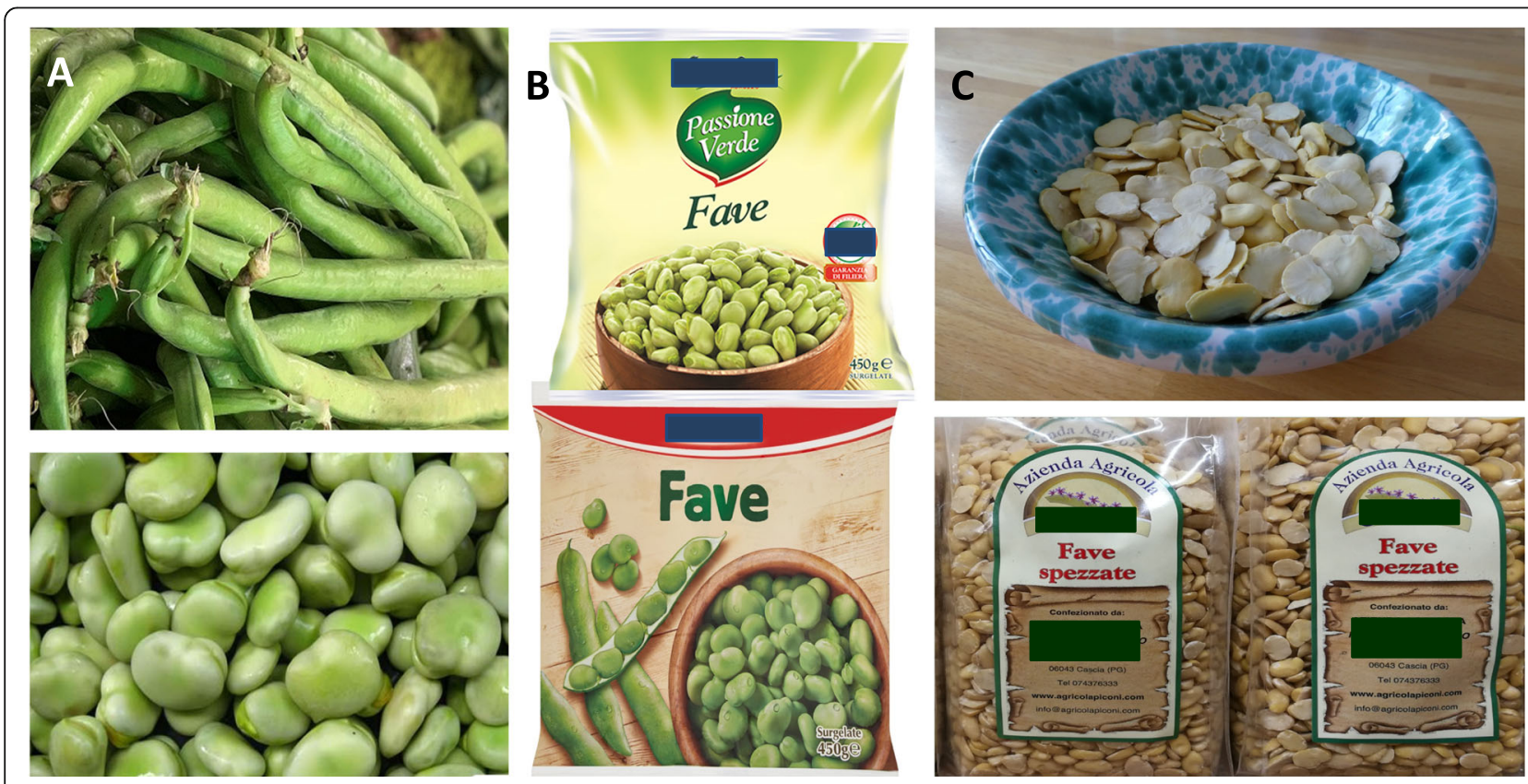

Fig. 6 Fresh and dry broad beans. a Pods (a) and seeds (b) of broad bean to be consumed fresh, as vegetable, during the season. $\mathbf{b}$ Packages of frozen broad beans, easily available in Southern European retailers, less common in other areas. Frozen faba beans (green) replace the fresh product well, but are more expensive. c Dry split broad beans (fave spezzate in Italian). Drying prolongs shelf life in a cheaper way than freezing. Skin removal allows to shorten preparation times compared to whole broad beans. The majority of broad beans are marketed as skinned split beans throughout the whole Mediterranean Basin and the Middle East 


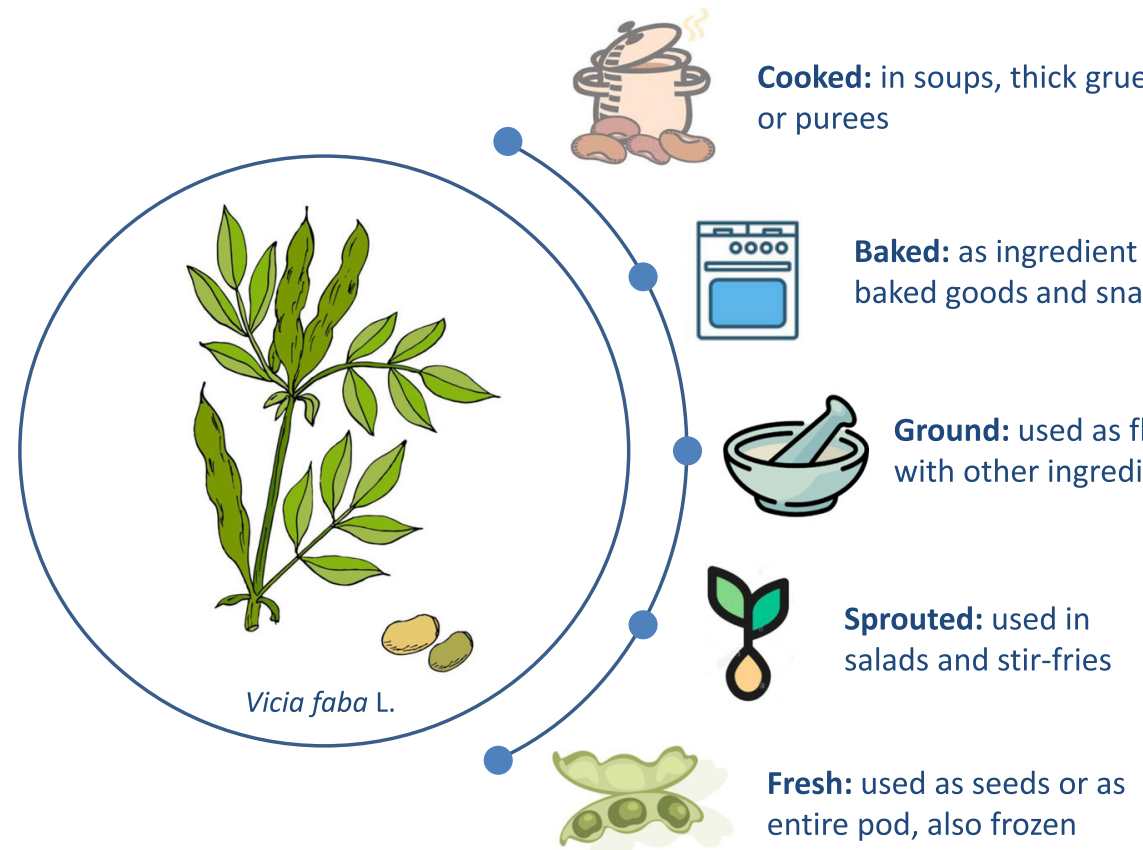

Fig. 7 Culinary use of broad beans. The culinary use of broad beans includes several different ways of cooking: stewing, baking, and frying. Each country has its own specific gastronomy. However, there is a link between recipes with broad beans across the Mediterranean Basin and the Middle East, because the most traditional preparations are invariably soups, thick gruels, and purees, with spices as the main element of differentiation. In addition, broad beans can be ground for subsequent use as flour mixed with other ingredients, or can be sprouted, to be used in salads and stir-fries

prepared by soaking skinned broad beans to soften, then draining them and adding chives, parsley, fresh coriander, garlic, dill, leek, green onions, baking soda, salt, and pepper to obtain a homogeneous mixture, which is portioned, shaped circularly, and externally seasoned with sesame seeds and dry coriander. The dumplings are deep-fried until golden, then served, still hot, with flatbread, tahini sauce, salad, and ful medames (Fig. 8) [43].

The origin of falafel is often, wrongly, attributed to Lebanon. Instead, falafel appeared in Egypt after the occupation by the English in 1882. The Egyptians were inspired by other types of fried croquettes (fish, meat,
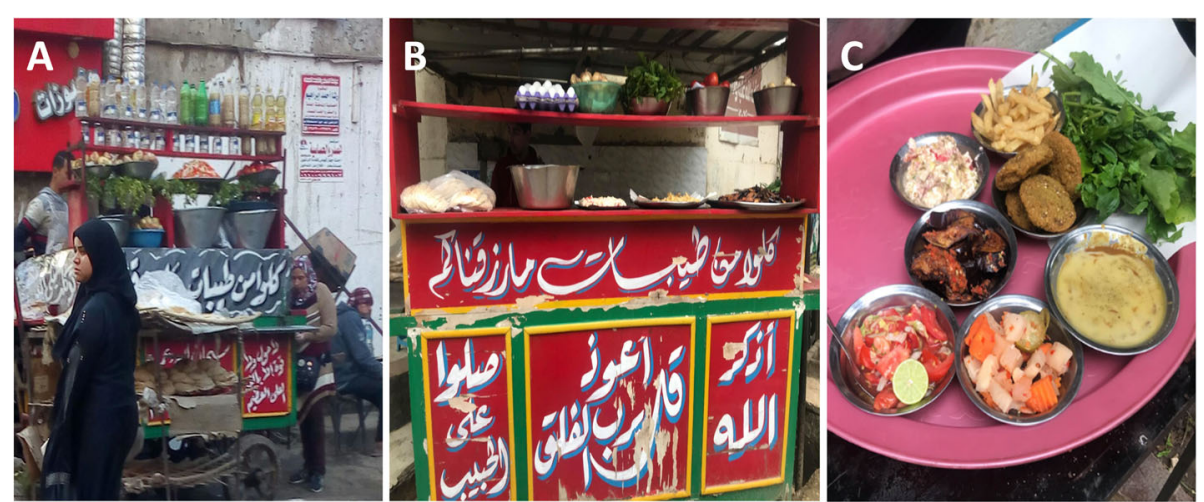

Fig. 8 Consuming ful medames in the street. a A carts typically used in Egypt by the street vendors of ful medames (A'rabeyet el-ful). b Usual decoration of the carts, depicting surah of the Quran, in this case the 113.01 and the 02.172 surah. The latter is related to food: Oh you who have believed, eat from the good things which We have provided for you and be grateful to Allah if it is [indeed] Him that you worship. c Traditional street serving composed of a dish, a ful medames seasoned with abundant tahini sauce, and, counterclockwise, ta'meya (broad bean fritters), fried potatoes, cottage cheese with diced tomato and oil, pickled eggplants, salad (finely diced tomato, onion, cucumbers, and lemon), and pickled vegetables. The fresh green is arugula 

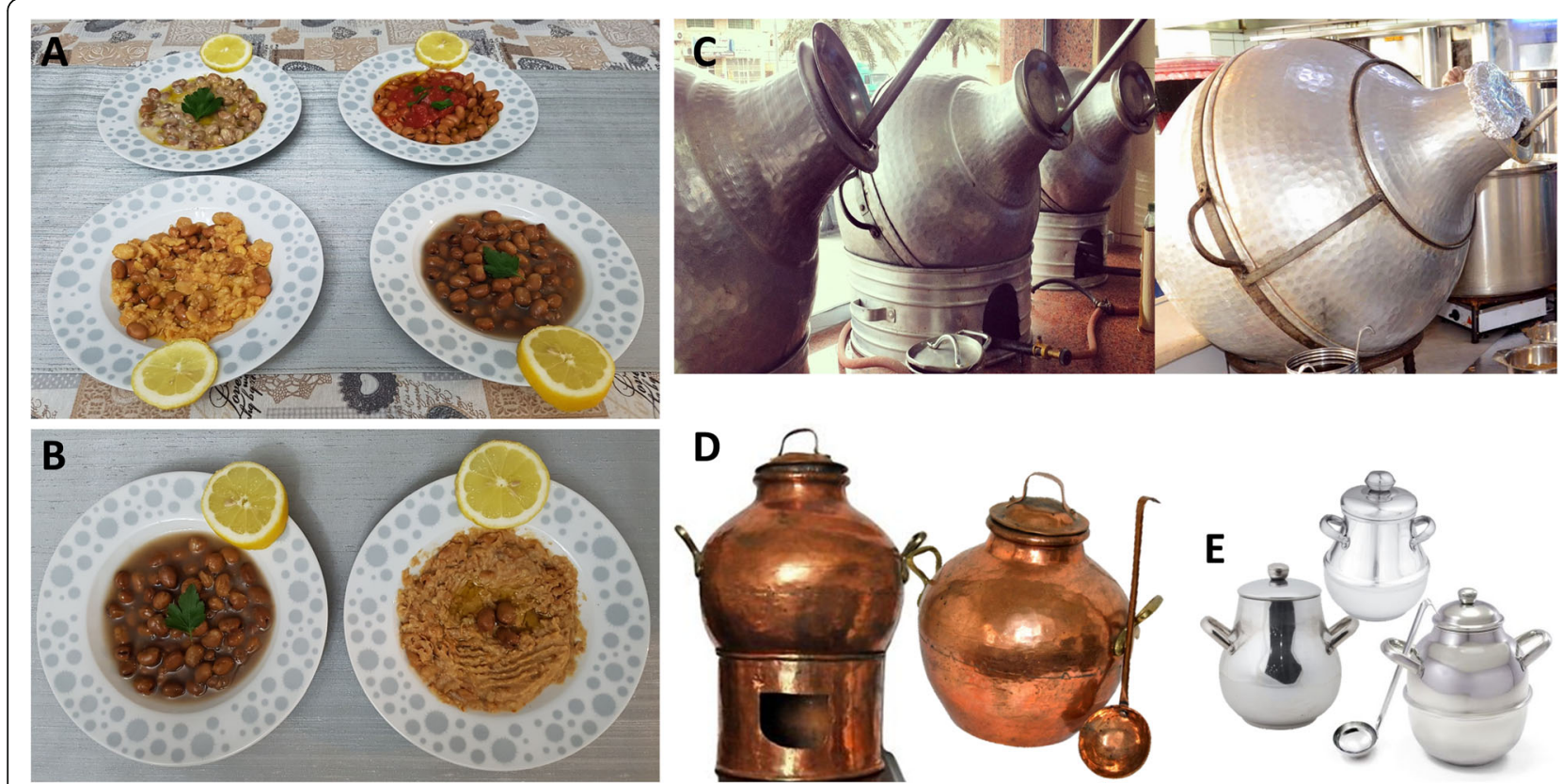

Fig. 9 Ful medames variants and traditional pots for preparing it. a Four types of ful medames, differently seasoned. Clockwise: with tahini sauce; with tomato sauce; with chili sauce; plain, i.e., seasoned with oil, lemon juice and cumin, which are the basic ingredients of any ful medames variant. b Ful medames in its whole and totally mashed version. Both types are plain. c Large aluminum pots for ful medames (damasa) used at the restaurants and take away in Egypt. These pots are artisanally made. $\mathbf{d}$ A copper damasa. This type of damasa is very traditional and is handcrafted. e A group of small stainless steel industrially made damasa for domestic use, modern. The size of damasa changes from small, only for domestic use, to large, such as those of the street vendors and restaurants

vegetable) originating from India and introduced by the British troops coming from there [45].

Another broad bean-based dish, whose preparation is similar to ful medames but involves the use of skinned beans, is the bissara. Bissara is found also in Moroccan cuisine. In Egypt, however, bissara is eaten exclusively as a dip for bread, whereas in Morocco, bissara can be either a dip or a soup. Moreover, Egyptian bissara has a green appearance, because its ingredients include herbs or leafy greens, such as parsley and coriander, mashed along with the beans. Other ingredients are vegetable oil, lemon juice, garlic, and cumin.

Fresh broad beans or ful akhdar ("green ful") are also consumed in Egypt, as well as broad bean sprouts or ful nabit (or nabid).

Particularly popular in Egypt, Jordan, Lebanon, and Syria, ful medames is consumed also in Eritrea, Somalia, Ethiopia, Sudan, and Yemen. Furthermore, this dish is similar to several other Mediterranean broad beanbased culinary preparations, differing from ful medames only for the type of spices or herbs added and the final consistency of the dish.

\section{Ethiopia: Shahan ful}

Ethiopia is the second global producer of broad beans [9]. In rural areas, these legumes play a fundamental role in preventing child malnutrition [46]. Shahan ful is quite common in Ethiopia as well as in Eritrea and Sudan. It is prepared in the same way as ful medames. Once the beans have softened, they are crushed into a coarse paste and served with chopped green onions, tomatoes, hot green peppers, yogurt, feta cheese, olive oil, tesmi (spicy clarified butter), berbere (a traditional spice blend), lemon juice, cumin, and chili pepper. The dish is consumed more frequently during Ramadan and Lent.

Baqella nifro, meaning "boiled broad beans" in Amharic, are eaten during the period of mourning and on some religious holidays [47]. On the Thursday before Good Friday, to honor the Last Supper of Jesus Christ, Ethiopian Orthodox people traditionally eat the gulban, made of boiled broad beans and wheat, seasoned with a blend of hot spices.

Broad beans are also milled to flour, which is the basic ingredient of several traditional Ethiopian dishes having the appearance of a puree. Hilibet (or hlbet) is a paste of broad bean flour, seasoned with a sauce made of onion, tomato, and spices, consumed with the Ethiopian flatbread injera and stews [47, 48]. Siljo is prepared by cooking broad bean flour in a safflower extract to obtain a semi-solid slurry, then adding black mustard powder and allowing to ferment several hours until a sour taste is developed [48, 49]. Rue leaves and garlic are added 
before consumption [48]. Siljo is particularly popular in the central highlands of Ethiopia during the fasting period preceding Easter [48].

Broad beans are one of the main components of shiro, a flour from a blend of roasted legumes (broad beans, peas, lentils, chickpeas), which is the basis of a creamy puree ("shiro wet") very cheap and ubiquitously consumed in Ethiopia [49].

\section{Tunisia: Ful bi'l-kammun}

Ful medames is consumed also in Tunisia, seasoned with abundant cumin and therefore named ful bil-kammun, i.e., "broad beans in cumin." To prepare it, broad beans are boiled with lemon, then strained and seasoned with olive oil, cumin, and harissa, the hot chili pepper paste traditionally used in Tunisia, Algeria, and Morocco.

\section{Morocco: Bissara}

Bissara (or bessara/besarah/paysar) is a broad beanbased dish very popular in Northern Morocco, particularly at breakfast. Prepared also in Egypt, the Moroccan version of bissara is different from the Egyptian one. Broad beans are boiled with some garlic and salt, then finely mashed after cooking. The dish is seasoned with olive oil, cumin, and paprika [50]. The final consistency varies from a creamy soup to a puree. Bissara is sometimes prepared using split peas or chickpeas.

\section{Algeria: Doubara}

In Algeria, the doubara is a soup of broad beans, eventually mixed with chickpeas, seasoned with salt, garlic, tomato sauce, coriander, cumin, lemon, oil, and paprika. Also, the bissara is commonly eaten in Algeria, usually prepared as puree and spiced with cumin and paprika.

Another dish, traditional of North-Eastern Algeria, is the harira ful, i.e., a soup of legumes (mostly broad beans either dried or fresh) and vegetables [51].

\section{Malta: Bigilla}

Broad beans are largely consumed also in Malta. A local popular dish is the ful bit-tewm, meaning in Maltese "broad beans with garlic." Ful bit-tewm is usually prepared in Spring with fresh broad beans and is associated with fasting during Lent and Good Friday. For the rest of the year, dried broad beans are used, which have to be soaked in water overnight, cooked with garlic and mint, then dressed with olive oil or vinegar before serving.

Ful bit-tewm is prepared with whole broad beans, without mashing them, whereas another traditional Maltese broad bean-based dish named bigilla requires mashing. To prepare the bigilla, broad beans are soaked overnight, then simmered until they are soft and the liquid is absorbed. The beans are then mashed with a fork, added chopped garlic, and garnished with fresh parsley. Just before serving the dish, olive oil is added [52]. Similarly to ful medames in Egypt, bigilla was sold by street vendors running around the villages with small vans. Today, bigilla is also industrially made and marketed as a delicacy (Fig. 10).

Being Malta at the center of the Mediterranean Basin, its gastronomy is the result of Southern Italian, Spanish, Arabic, and Turkish influences. Bigilla is mentioned in the Maltese-Italian-Latin dictionary of Canonico Agius De Soldanis (1712-1770), a document of the eighteenth century where many Maltese gastronomic words are listed. Furthermore, the Hierolexicon of Domenico Magri [35] explains that bigilla derives from the ancient Turkish word bagkala or bagala (currently bakla, i.e., "broad bean").

Mirroring the ideas concerning broad beans in antiquity [31], bigilla had a special symbolic value in Malta, being a typical "funeral food" [36]. Traditionally, it was distributed to the poor people or to the bekkejja, professional whiners accompanying the deceased to the church [35].

\section{Italy (Apulia): Puré di fave e cicorie}

In Apulia, a region of Southern Italy, a very traditional dish is puré di fave e cicorie (Fig. 11), i.e., "puree of broad beans with chicories" [53]. The puree of broad beans is prepared in the same way as ful medames and bigilla, but skinned broad beans are used to fasten cooking and to ensure a golden color also when brown or violet seeds are used. After cooking, the broad beans are pressed through a fine-meshed sieve to obtain a homogeneous puree.

To soften the consistency of puree and smooth its taste, a small potato may be added while cooking the beans, which will be mashed altogether, despite taste "purists" not accepting this variant. No spices are added, but the puree is typically served with boiled wild chicories, adding salt and a drizzle of oil to the dish [53]. Wild chicories are very bitter; therefore, the combination with the broad bean puree, which is sweeter, dilutes their strong taste [54].

Alternatively, the puree of broad beans can be combined with other ingredients, such as pasta, seafood, eggplants, and with the wild bulbs of tassel hyacinth (Leopoldia comosa (L.) Parl.). The latter, locally named lampascione, is considered a delicacy [54].

The habit of consuming non-cultivated edible plants was particularly common in the recent past in rural areas due to economic reasons. Also, broad beans were considered "the meat of the poor" because these were eaten to substantiate poor tables. Therefore, wild edible herbs and legumes were typical of peasant diet because these were the cheapest food. Nowadays these dishes are 

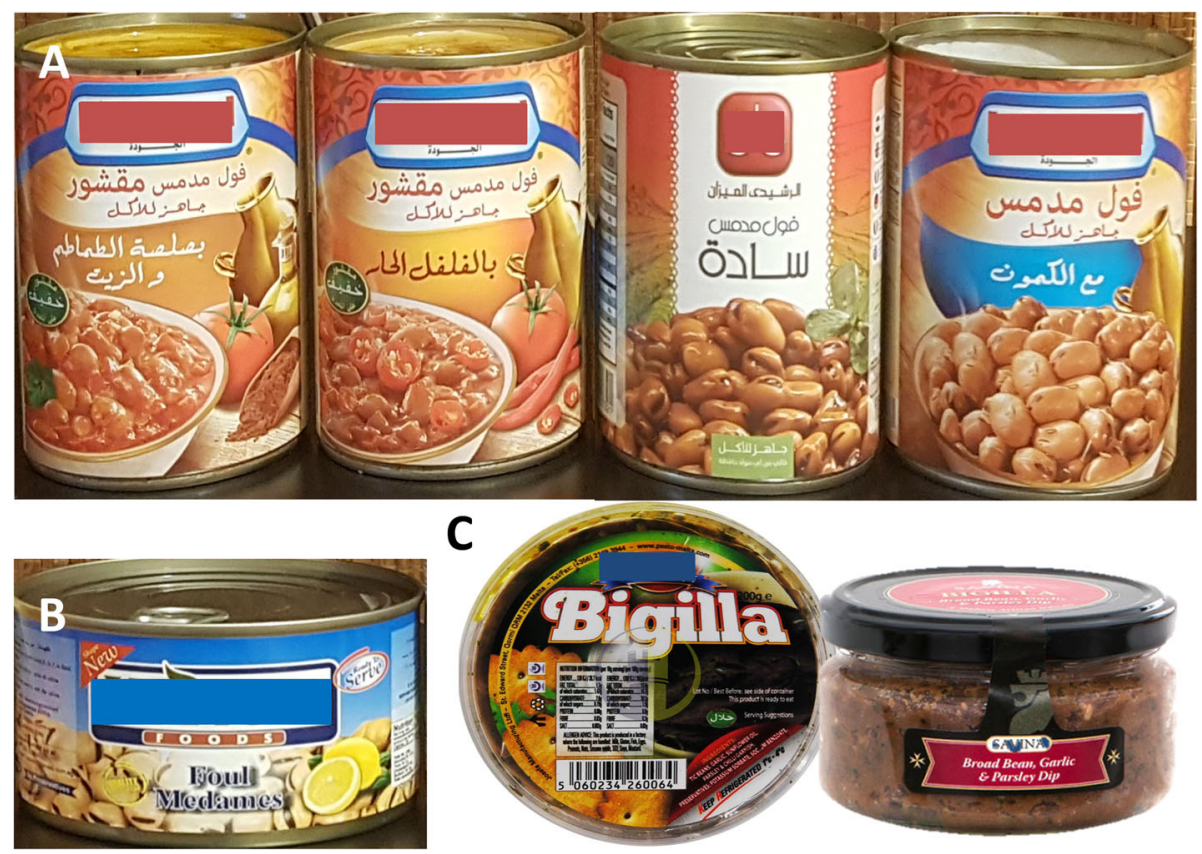

Fig. 10 Canned broad bean-based foods. a Skinned boiled broad beans with oil and tomato sauce; with tomato and chili; plain; with cumin, all available at Egyptian retailers. b Canned Egyptian ful medames, useful to skip the long home preparation, consisting in soaking broad beans in water and cooking slowly on the stove with a very faint flame, until tender ( 6 or $7 \mathrm{~h}$ ). c A couple of cans of Maltese bigilla from different companies. Bigilla is a traditional Maltese broad bean-based dish prepared in a similar way as ful medames. At the time, the bigilla was prepared and sold by street vendors running around the villages with small vans, as a cheap and quite common food, whereas today, it can be industrially produced and is marketed as a delicacy

still a simple domestic food, but are also served at the best restaurants.

In many Apulian towns, the tradition of eating boiled broad beans (a very simple version of ful medames, without any seasoning) on the day of Saint Anthony (January 17th) is still alive [53]. In that occasion, communal bonfires are lit in the main town squares, and unpeeled broad beans, soaked in water in traditional clay containers (pignata), are cooked next to the fire (Fig. 11). These containers have two handles on the same side, so that a long stick can be inserted to remove it easily from the fire (Fig. 11). Once cooked, the broad beans are mixed with olives and distributed to people (Fig. 11).

The cult of Saint Anthony is related to the fire because this Saint is believed to protect from the herpes zoster, popularly called "St. Anthony's fire" [55]. The popular festivals in which fire is the protagonist are mostly concentrated around the end of the year when, after the winter solstice, the days begin to lengthen again, like a new season of life [55]. On the day of St. Anthony, also special breads are produced, which are blessed and distributed to the people together with the broad beans, as a symbol of the gifts of the earth. The ashes left after the bonfire are scattered in the fields to wish a good harvest.

\section{Italy (Sicily): Macco}

In the Italian island of Sicily, broad beans are used to prepare the macco, in a very similar way as the Egyptian ful medames. Broad beans are soaked overnight, simmered with laurel leaves, mashed, mixed with pasta, and seasoned with pepper and olive oil [56].

Variants of the macco involve the use of fennel, cooked together with the beans, and eventually the addition of tomato and onion, without pasta. Also, fresh broad beans (fave fresche) are used, in the variant macco di fave fresche [56].

\section{Greece: Koukia}

Koukia, meaning "broad beans" in Greek (singular = kouki), is a dish prepared by boiling fresh broad bean pods, then draining and frying with onion and garlic. The dish is seasoned with some dill, pepper, and lemon juice. Other vegetables can be added, such as artichokes (aginares me koukia) [57].

\section{Turkey: Bakla}

Bakla (also called fava) means "broad bean" in Turkish and is also the name of a popular broad bean puree. Broad beans, soaked before cooking, are boiled with some onion, then mashed and sieved to obtain a smooth 

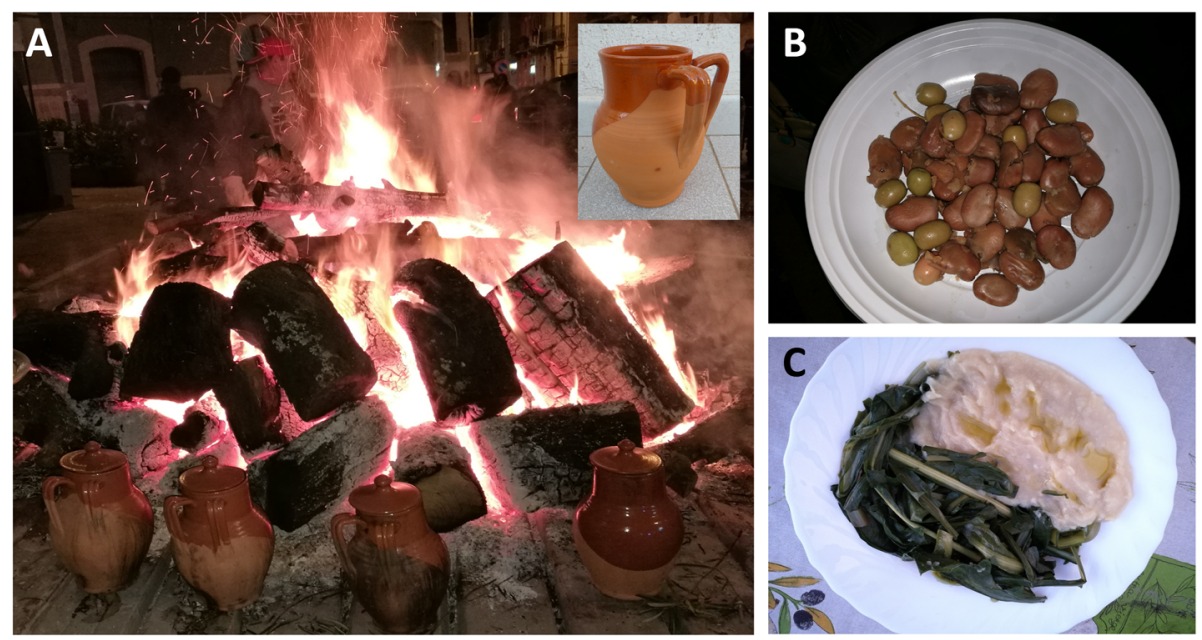

Fig. 11 Southern Italian traditions related to broad-beans. a A communal bonfire traditionally made to celebrate Saint Anthony's day (January, 17) in Southern Italy. The picture has been taken in Giovinazzo, in the Apulia region. Broad beans are being cooked close to the fire in traditional clay containers (locally named pignata) having two handles in which a long stick can be inserted to remove them from the fire. $\mathbf{b} \mathrm{A}$ dish of boiled broad beans, mixed with olives, distributed to people on Saint Anthony's day in Giovinazzo, Italy. c A dish of puré di fave e cicorie, composed of a broad bean puree combined with wild chicories. This dish represents one of the most traditional and appreciated Apulian culinary preparations (Southern Italy)

puree, which is seasoned with lemon juice and red pepper [58].

Zeytinyağl bakla, i.e., "broad beans in olive oil," are prepared with take bakla (meaning "fresh broad beans in their pods"), chopped onions, tomatoes, garlic, lemon, and olive oil. Garlic yogurt is needed for serving, and a little dill/dereotu is used for garnishing [58].

\section{Iraq: Bagilla bil-dihin}

Broad beans, named bagilla in Iraq, are used to prepare the bagilla bil-dihin (meaning "broad beans with fat"), which is the Iraqi counterpart of the Egyptian ful medames [59]. This dish, very popular at breakfast, is also called tashreeb bagilla (being other spelling tishreeb, tarheed, and thareed bagilla) and is prepared by soaking flatbread pieces in the cooking water of broad beans, then adding the cooked broad beans on the top, together with ghee, fried eggs, and onion [59]. Broad beans are often consumed in combination with rice, seasoned with dill, such as in the timman bagilla ("rice and broad beans"), where broad beans can be either fresh or dried [59].

\section{Iran: Baghalee pokhte}

Broad beans (baghalee or baghali in Persian) represent the basis of many traditional Iranian dishes. Baghalee pokhte is a typical finger food composed of boiled (pokhte) broad beans spiced with paprika, pepper, salt, and eventually vinegar, to be eaten one by one, removing the peel [47]. Baghali ghatogh, instead, is a dish made by stewing fresh broad beans with dill, garlic, turmeric, and egg [60], whereas baghalee polo is "broad beans with rice" [47].

\section{Conclusion}

In conclusion, broad beans are much more than a cheap source of nutrients. Among the oldest domesticated legumes, they have a cultural value linked to an ancient symbolic meaning. Generally associated with funerary rituals, broad beans have also a positive significance because of their regenerative capacity, parallel to the beginning of daylight increase in the period in which they are sown.

The study highlights a link between broad bean-based dishes in different countries around the Mediterranean Basin and in the Middle East, despite the different combinations of seasonings and slightly different procedures. Similar environmental conditions, which lead to the availability of the same raw materials, as well as cultural exchanges and interactions along trade routes, are the main determining factors that can explain this link. Few Mediterranean dishes can be imagined without such exchanges. The continuous combination of these two factors over time has shaped eating habits in this vast geographic area and has generated the Mediterranean diet.

Broad beans, therefore, are constantly present in the foodscape of the Mediterranean and Middle Eastern countries, being soups, thick gruels, or purees the most traditional preparations. Particularly popular is ful medames, typical of Egypt but prepared throughout the 
Middle East and consumed also in Eritrea, Somalia, Ethiopia, Sudan, and Yemen. Furthermore, ful medames is very similar to an array of broad bean-based dishes from other Mediterranean countries, differing mostly in the type of spices or herbs added for seasoning them.

Considered that broad beans are little consumed and even little known in Northern Europe and the USA, enhancing the knowledge of these ethnic tasty culinary preparations could improve the diet of Western countries by increasing the consumption of legumes.

\section{Acknowledgements}

The authors kindly acknowledge Luigi Ricciardi and Stefano Pavan of the University of Bari, Italy, for furnishing the $V$. faba samples; Fouzia Kadri (Algeria), Zeynep Merve (Turkey), Mohamed Ramadan (Egypt), and Ashwak A. Hassan (Egypt) for helpful discussions; and Francesco Barile (Italy) for skillful cultivation of the faba bean plants in the pictures. This research has been developed in the framework of the activities of the "Centro

Interdipartimentale di Ricerca per la Cooperazione allo Sviluppo" (CPS) of the University of Bari, Italy.

\section{Authors' contributions}

AP conceptualized the research, reviewed the literature, interpreted the data, and wrote the article. AA and CS provided data and information. CS acquired funding. AP, AA, and CS revised, read, and approved the final manuscript.

\section{Funding}

This research has been performed within the project "LEgume GEnetic REsources as a tool for the development of innovative and sustainable food TEchnological system" supported under the "Thought for Food" Initiative by Agropolis Fondation (through the "Investissements d'avenir" program with reference number ANR-10-LABX-0001-01"), Fondazione Cariplo, and Daniel \& Nina Carasso Foundation.

\section{Availability of data and materials}

All data and materials have been presented in the paper.

\section{Competing interests}

The authors declare that they have no competing interests.

\section{Author details}

${ }^{1}$ Department of Soil, Plant and Food Science (DISSPA), Food Science and Technology Unit, University of Bari 'Aldo Moro', Via Amendola, 165/a, I-70126 Bari, Italy. ${ }^{2}$ Ahmed Oraby Street, Suez, Egypt.

Received: 29 March 2020 Accepted: 28 October 2020

\section{Published online: 10 November 2020}

\section{References}

1. Caracuta V, Barzilai O, Khalaily H, Milevski I, Paz Y, Vardi J, Regev L, Boaretto E. The onset of faba bean farming in the Southern Levant. Sci Rep. 2015;5: 14370.

2. Mikic A. Origin of the words denoting some of the most ancient Old World pulse crops and their diversity in modern European languages. PLoS One. 2012:7:e44512.

3. Kopke U, Nemecek T. Ecological services of faba bean. Field Crops Res. 2010;115:217-33.

4. Merga B, Egigu MC, Wakgari M. Reconsidering the economic and nutritional importance of faba bean in Ethiopian context. Cogent Food Agric. 2019;5: 1683938.

5. Elwakil MA, El-Refai IM, Awadallah OA, El-Metwally MA, Mohammed MS. Seed-borne pathogens of faba bean in Egypt: detection and pathogencity. Plant Pathol J. 2009:8:90-7.

6. Stringi L, Giambalvo D. Fava (Vicia faba L.). In: Leguminose e agricoltura sostenibile. Bologna: Calderini editore; 2001.

7. Vioque J, Alaiz M, Girón-Calle J. Nutritional and functional properties of Vicia faba protein isolates and related fractions. Food Chem. 2012;132:67-72.
8. Crépon K, Marget P, Peyronnet C, Carrouée B, Arese P, Duc G. Nutritional value of faba bean (Vicia faba L.) seeds for feed and food. Field Crops Res. 2010;115:329-39.

9. Food and Agriculture Organization. Data of Crops Production; 2017. http:// www.fao.org/faostat/en/\#data/QC. Accessed 7 October 2019.

10. Ofuya ZM, Akhidue $V$. The role of pulses in human nutrition: a review. J Appl Sci Environ Manag. 2005;9:99-104.

11. Grela ER, Günter KD. Fatty acid composition and tocopherol content of some legume seeds. Anim Feed Sci Tech. 1995;52:325-31.

12. Mateos-Aparicio I, Redondo-Cuenca A, Villanueva-Suárez MJ, Zapata-Revilla MA, Tenorio-Sanz MD. Pea pod, broad bean pod and okara, potential sources of functional compounds. LWT-Food Sci Technol. 2010;43:1467-70.

13. Amarowicz R, Troszyńska A, Baryłko-Pikielna NINA, Shahidi F. Polyphenolics extracts from legume seeds: correlations between total antioxidant activity, total phenolics content, tannins content and astringency. J Food Lipids. 2004;11:278-86.

14. Chaieb N, González JL, López-Mesas M, Bouslama M, Valiente M. Polyphenols content and antioxidant capacity of thirteen faba bean (Vicia faba L.) genotypes cultivated in Tunisia. Food Res Int. 2011;44:970-7.

15. Cucci G, Lacolla G, Summo C, Pasqualone A. Effect of organic and mineral fertilization on faba bean (Vicia faba L.). Sci Hortic. 2019:243:338-43.

16. Nozzolillo C, Ricciardi L. Proanthocyanidin content of broad bean seeds: relationship of seed coat color. In: Plant polyphenols. Boston: Springer; 1992. p. 911-4.

17. Sharma A, Sehgal S. Effect of processing and cooking on the antinutritional factors of faba bean (Vicia faba). Food Chem. 1992;43:383-5.

18. Khalil $\mathrm{AH}$, Mansour $\mathrm{EH}$. The effect of cooking, autoclaving and germination on the nutritional quality of faba beans. Food Chem. 1995;54:177-82.

19. Duc G, Marget P, Esnault R, Le Guen J, Bastianelli D. Genetic variability for feeding value of faba bean seeds (Vicia faba L.). Comparative chemical composition of isogenics involving zero-tannin and zero-vicine genes. J Agric Sci. 1999;133:185-96.

20. Oomah BD, LuC G, Leprelle C, Drover JC, Harrison JE, Olson M. Phenolics, phytic acid, and phytase in Canadian-grown low-tannin faba bean (Vicia faba L.) genotypes. J Agric Food Chem. 2011;59:3763-71.

21. Siah S, Wood JA, Agboola S, Konczak I, Blanchard CL. Effects of soaking, boiling and autoclaving on the phenolic contents and antioxidant activities of faba beans (Vicia faba L.) differing in seed coat colours. Food Chem. 2014;142:461-8.

22. Pasqualone A, Costantini M, Coldea TE, Summo C. Use of legumes in extrusion cooking: a review. Foods. 2020;9:958.

23. Bottini E. Favism: current problema and investigations. J Med Genetics. 1973;10:154-7.

24. Jamalian J, Ghorbani M. Extraction of favism-inducing agents from whole seeds of faba bean (Vicia faba L. var major). J Sci Food Agric. 2005;85:1055-60.

25. Hussein L, Motawei H, Nassib A, Khalil S, Marquardt RR. The complete elimination of vicine and convicine from the faba beans by combinations of genetic selection and processing techniques. Plant Foods Hum Nutr. 1986; $36: 231-42$.

26. Cardador-Martinez A, Maya-Ocaña K, Ortiz-Moreno A, Herrera-Cabrera BE, Dávila-Ortiz G, Múzquiz M, Martín-Pedrosa M, Burbano C, Cuadrado C, Jiménez-Martínez C. Effect of roasting and boiling on the content of vicine, convicine and L-3, 4-dihydroxyphenylalanine in Vicia faba L. J Food Quality. 2012;35:419-28.

27. Rizzello CG, Losito I, Facchini L, Katina K, Palmisano F, Gobbetti M, Coda R. Degradation of vicine, convicine and their aglycones during fermentation of faba bean flour. Sci Rep. 2016;6:1-11.

28. Hefni M, McEntyre C, Lever M, Slow S. A simple HPLC method with fluorescence detection for choline quantification in foods. Food Anal Methods. 2015;8:2401-8

29. Rabey JM, Shabtai H, Graff E, Korczyn AD. Improvement of Parkinsonian features correlate with high plasma levodopa values after broad bean (Vicia faba) consumption. J. Neurol Neurosurg Psychiat. 1992:55:725-7.

30. Zeisel SH, Blusztajn JK. Choline and human nutrition. Annu Rev Nutr. 1994; 14:269-96.

31. Binde P. Bodies of vital matter: notions of life force and transcendence in traditional Southern Italy. Göteborg: Acta Universitatis Gothoburgensis; 1999.

32. Pedroni L. I Fabi, Remo e le fave: assonanze e suggestioni. Faventia. 2010;32: 59-72.

33. Camporesi P. The magical harvest: food, folklore and society. Cambridge: Polity Press; 1993. 
34. Scarpi P. Religioni. Sistemi religiosi e ordine alimentare. In: Montanari M, editor. Cultura del cibo. Vol. 4. Il cibo nelle arti e nella cultura. Milano: UTET; 2015. p. 295-319.

35. Magri D. Hierolexicon sive Sacri Dictionarii. Venezia; 1788

36. Cassar-Pullicino G. Antichi cibi maltesi. Melita Historica. 1961;3:31-54

37. Tozzi Di Marco A. Offerte di cibo e convivi nell'Islam popolare della Città dei morti del Cairo: osservazione partecipante e riflessioni dal campo. In: Atti X Congresso Nazionale dell'A.IS.E.A - Associazione Italiana Scienze demo-etnoantropologiche. Cibo e alimentazione. Tradizione, simboli, saperi. Roma: CNR; 2006. p. 202-10

38. Tragni B. II cibo dei morti. Bari: Palomar; 2006.

39. Lawson J. Modern Greek folklore and ancient Greek religion: a study in survivals. Cambridge: Cambridge University Press; 1910.

40. Pelagalli A. Le fave dei morti, fra storie e antichi riti. Napoli: Albano Editore; 2013.

41. General Assembly of the Organization of the United Nations. 68th Session, Resolution adopted by the General Assembly on 20 December 2013 [on the report of the Second Committee (A/68/444)] 68/231. International Year of Pulses, 2016; 2014. https://www.un.org/en/sections/observances/ international-years/index.html Accessed March 192020

42. Torres AM, Avila CM, Stoddard FL, Cubero JI. Faba bean. In Pérez de la Vega M, Torres AM, Cubero II, Kole C, editors. Genetics, genomics and breeding in crop plants: cool season food legumes. Plymouth: Science Pubs Inc; 2012.

43. Nathan T. Ce pays qui te ressemble. Paris: Stock Editor; 2015.

44. Pasqualone A. Traditional flat breads spread from the Fertile Crescent: production process and history of baking systems. J Ethnic Foods. 2018;5: 10-9.

45. Essid M. History of Mediterranean food. In: CIHEAM editor, MediTERRA 2012: The Mediterranean diet for sustainable regional development. Paris: Presses de Sciences Po; 2012. p. 51-69.

46. Negash C, Belachew T, Henry CJ, Kebebu A, Abegaz K, Whiting SJ. Nutrition education and introduction of broad bean-based complementary food improves knowledge and dietary practices of caregivers and nutritional status of their young children in Hula, Ethiopia. Food Nutr Bull. 2014:35:480-6.

47. Bilello S. 21st Century Homestead: nitrogen-fixing crops. Morrisville: Lulu Press; 2016.

48. Mehari T, Ashenafi M. Microbiology of siljo, a traditional Ethiopian fermented legume product. World J Microb Biot. 1995;11:338-42.

49. McCann JC. Stirring the pot: a history of African cuisine. Athens: Ohio University Press; 2009.

50. Wolfert P. The food of Morocco. New York: Harper Collins; 2011

51. Bizzarri P, Pelanda D. La fede nel piatto. Saperi e sapori del cibo dei poveri. Edizioni Paoline: Milano; 2008.

52. Sammut J. Maltese cooking. Sliema: Miller Publishing; 2008.

53. Sada L. La cucina della Terra di Bari. Padova: Franco Muzzio Editore; 1991.

54. Sada L. La cucina pugliese. Città di Castello: Newton e Compton Editori; 2003.

55. Gelmetti C. Il fuoco di Sant'Antonio: storia, tradizioni e medicina. Berlin: Springer Science \& Business Media; 2007.

56. Allotta A. La cucina siciliana. Città di Castello: Newton Compton Editori; 2003

57. Kochilas D. My Greek table. Boston: PBS; 2018.

58. Ozan O. Sultan's kitchen: a Turkish cookbook. Clarendon: Tuttle Publishing; 2012.

59. Nasrallah N. Delights from the Garden of Eden. A cookbook and a history of the Iraqi cuisine. Second Edition. London: Equinox Publishing; 2003.

60. Tehrani MM, Duffy M. The sensuous host: practices of ensuring guests feel 'at home' in traditional Iranian houses. J South Asian Stud. 2015:3:351-61.

\section{Publisher's Note}

Springer Nature remains neutral with regard to jurisdictional claims in published maps and institutional affiliations.

Ready to submit your research? Choose BMC and benefit from:

- fast, convenient online submission

- thorough peer review by experienced researchers in your field

- rapid publication on acceptance

- support for research data, including large and complex data types

- gold Open Access which fosters wider collaboration and increased citations

- maximum visibility for your research: over $100 \mathrm{M}$ website views per year

At $\mathrm{BMC}$, research is always in progress.

Learn more biomedcentral.com/submissions 